\title{
Piloleiomyoma Presented by Multiple Cutaneous Nodules: a Case Report
}

\author{
Lala CAHANGIROVA', Jamal MUSAYEV² \\ ${ }^{1}$ Department of Dermatology, Modern Hospital, Baku, Azerbaijan \\ ${ }^{2}$ Department of Pathology, Azerbaijan Medical University, Baku, Azerbaijan \\ Correspondence: Jamal Musayev, E-mail: patolog.jamalmusaev@gmail.com \\ UDC 616.52-091.8 \\ UDC 616.5-006.03-08
}

\begin{abstract}
Introduction. Piloleiomyoma is a rare benign tumor which is caused by erector pili muscle and makes up $5 \%$ of all leiomyomas. They can be solitary and multiple. Multiple lesions still pose challenges for clinicians since their treatment option is very limited. Case report. We report a case of a 25 -year-old male patient who had painful papules and nodules on the neck and chest for three years. Multiple red-brown papules and nodules in the skin of regio mammaria dextra and regio submandibularis on the left were seen on physical examination. Histopathological examination of punch biopsy sample revealed well-circumscribed nodule composed of spindle cells. The case was reported as cutaneous leiomyoma (piloleiomyoma). The patient was given $5 \mathrm{mg} /$ day amlodipin and kept under control. Conclusion. The ideal treatment option for piloleiomyoma is surgical excision, but the problem with that treatment is that the lesions have tendency to recur. Medicamentous therapy plays a limited role; however, calcium-channel blockers and $a$-adrenergic blockers may help in palliating or eliminating associated pain through inhibition of smooth muscle contraction.
\end{abstract}

Key words: Leiomyoma; Skin Neoplasms; Smooth Muscle Tumor; Biopsy; Calcium Channel Blockers; Adrenergic alphaAntagonists; Rare Diseases

\section{Introduction}

Cutaneous leiomyoma is a rare benign tumor caused by smooth muscle fibers. It was initially described by Virchow in 1854 (1). It is categorized into three groups, depending on the type of the tissue: angioleiomyoma, piloleiomyoma and genital leiomyoma (2). Especially the last two types can be very problematic for the patient due to pain and discomfort. Piloleiomyoma makes up 5\% of all leiomyomas (3). In this report, multiple piloleiomyoma case presented with clinical and pathological findings.

\section{Case Report}

The authors report a case of a 25-year-old male patient who had painful papules and nodules on the neck and chest for three years. There were not any ulceration and flow on lesions or systematic complaints. There were not any similar complaints in the family or first relatives of the patient. Birth and development of the patient was normal. Multiple red-brown papules and nodules in the skin of regio mammaria dextra (Figure 1a) and regio submandibularis on the left (Figure 1b) were seen on physical examination. Punch biopsy was taken from the lesions and sent for histopathological examination with initial diagnosis of molluscum contagiosum, piloleiomyoma, pilomatrixoma and sarcoidosis. Histopathological examination revealed well-circumscribed nodule composed of spindle cells in the dermis (Figures 2 a and b). Atypia, mitotic activity and necrosis were not seen in spindle cells. According to histopathological findings the case was reported as cutaneous leiomyoma (piloleiomyo$\mathrm{ma}$ ). The patient was given $5 \mathrm{mg} /$ day amlodipin and kept under control.

\section{Discussion}

The classification of cutaneous leiomyomas is based on the type of smooth muscle which develops the lesion. Piloleiomyoma arises from the smooth muscle of the hair (erector pili) while angioleiomyoma stems from smooth muscle of the vessels (4). The 

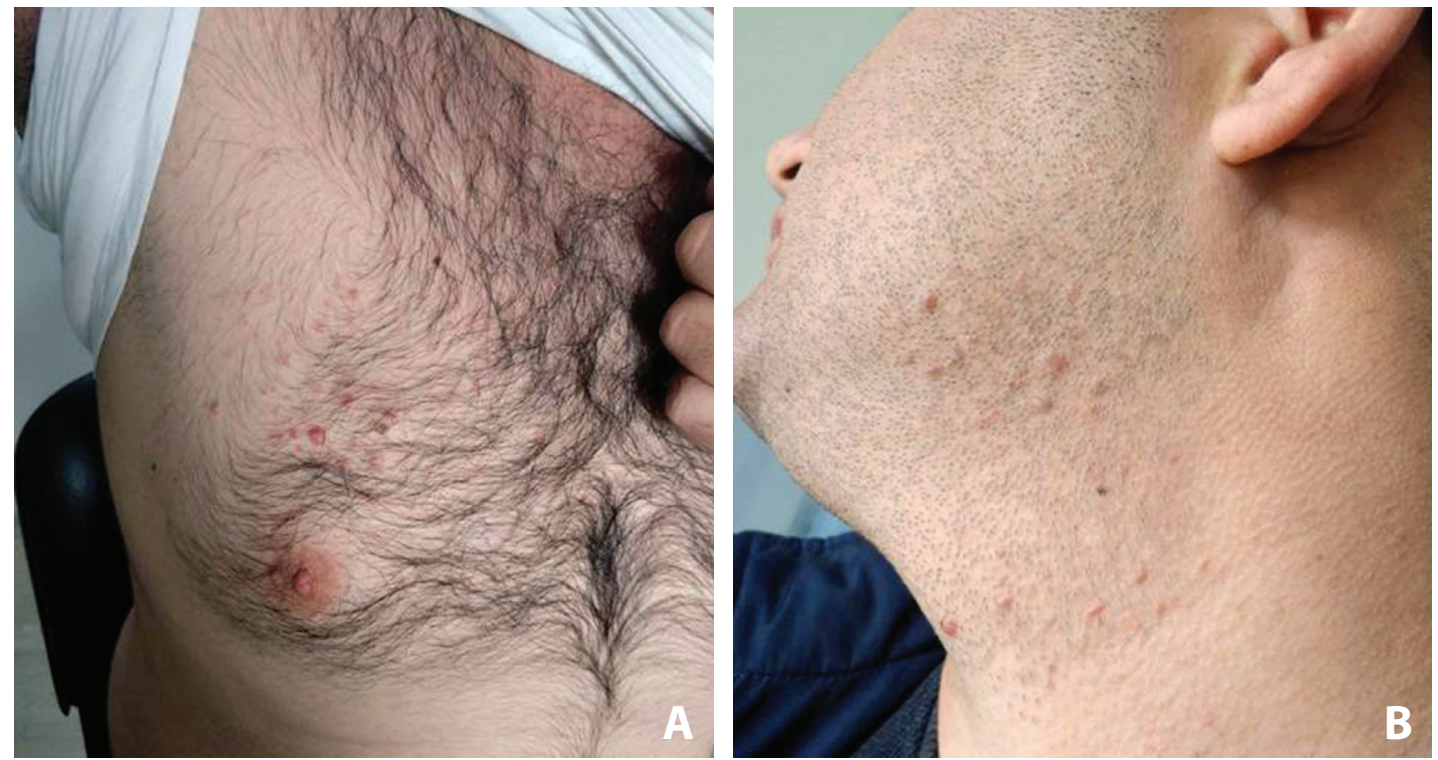

Figure 1. Multiple red-brown papules and nodules in the skin of right mammary region

(A) and left submanfdibular region (B).

lesions of dartos muscle of the scrotum, labia majoris and erectile muscle of the nipple are classified under genital leiomyoma (4).

In 1880 Besnie classified leiomyomas as solitary and multiple (3). Multiple piloleiomyoma develops generally between the ages of 10 and 30; however, solitary piloleiomyoma develops further in life.

Although it can be seen in patients of varying age groups, it is more frequently seen between the second and fourth decade of life (1, 4). Arishima et al reported a 6-year-old boy with a vascular leiomyoma and Lotfi et al presented a 5-month-old boy with cutaneous leiomyoma; furthermore, there are isolated case reports of children, including a case where light brown lesions were discovered on the soles of a newborn $(5,6)$. Leiomyomas do not depend on gender or race and can be developed sporadically or transmitted genetically (7).

Cutaneous leiomyomas can be located asymmetrically on the extensor muscles of the limbs, chest, face and even on the scalp (8). Genital leiomyomas are solitary papulonodules or pedunculated papules located on the scrotum, vulva, or nipple. Angioleiomyomas, which include solid, cavernous, or venous subtypes, are derived from the tunica media of small arteries and veins and typically present on the extremities (9).
Solitary and multiple piloleiomyoma are different entities. In women, multiple cutaneous leiomyoma can be associated with uterine leiomyomas as a part of Reed's syndrome (10). Multiple piloleiomyomas have different kinds of dispersion. The most common is grouped dispersion, as well as disseminate, segmental and zosteriform type dispersions can be seen. The common localization for multiple piloleiomyomas is the trunk, while for solitary lesions it is limbs $(4,11)$.

The main discomfort of the lesions is the pain and there are two points of view about the cause of pain. According to one of them, the tumor in itself puts pressure on the nerves; therefore, the patient feels pain. Other scientists claim that the pain is caused by the contractions of the muscle which is triggered by cold weather, friction and emotions (3).

Solitary lesions may be confused with dermatofibroma, pseudolymphoma, trichoepithelioma, lipoma, cylindroma, poroma even Leishmania (12). Multiple lesions should usually be differentiated from molluscum contagiosum, sarcoidosis, neurofibroma, angiolipoma, nevus, lipoma, eccrine spiradenoma, metastases and angioleiomyoma (4).

Histopathologically, cutaneous leiomyomas are not different from other leiomyomas and they consist of spindle cell proliferation, a mixture of collagen and smooth muscle cells, 
presented by well-circumscribed nodules. The tumor is usually located in the reticular dermis; in some cases, the lesion may grow to papillary dermis and can be a cause of flattening and thinning of the surface epidermis. The borders of tumor are prominent, but there is no capsule (13). Smooth muscle cells that form the tumor have fibrillary eosinophilic cytoplasm and bluntended nuclei. Although no significant atypia was observed in these cells, moderate anisonucleosis in the nuclei, hyperchromasia and pleomorphism in the $10 \%$ of general cell population can be seen in some cases. Prominent nucleoli have not been reported. Necrosis and mitotic activity were not observed in these lesions. The relationship between lesion and peripheral nerves appears more clearly in angioleiomyomas (13). On immunohistochemical examination, diffuse cytoplasmic staining with smooth muscle actin in spindle cells is characteristic. Smooth muscle actin and S100 have an important role in differentiation of these lesions from neurofibromatosis. The low staining rate with Ki 67 and staining profile of p53 can distinguish these lesions from malignant counterparts (13-15). Molecular studies showed fumaratehydratase germ mutation in all cases presenting with multiple lesions. In cases with mutations, these lesions can be cu- taneous manifestation of Multiple Cutaneous and Uterine Leiomyomatosis (MCUL, OMIM 150800) and Hereditary Leiomyomatosis and Renal Cell Carcinoma (HLRCC, OMIM 605839) syndromes (16).

Spontaneous regression is not characteristic for the majority of piloleiomyomas (10). Treatment depends on our expectations and therefore it is divided into two types: cosmetic and symptomatic. In general, to achieve the cosmetic aim solitary piloleiomyoma is extracted by surgery. But recurrences have been reported to occur from six weeks to more than 15 years following excision (10). But the same treatment method cannot be realized on multiple piloleiomyoma, and in that case we should prevent the symptoms. When multiple lesions are present and painful, calcium channel blockers or alpha-adrenergic blockers can help. In some cases gabapentin has been reported as a method for treating the pain (17). Cryotherapy and electrocoagulation is an alternative treatment method but according to studies they are not so effective. Ablation therapy by $\mathrm{CO}_{2}$ laser has satisfactory results (18). Moreover, injection of Botulinum toxin might be offered as an adjuvant therapy for pain relief by inhibiting the release of neu-
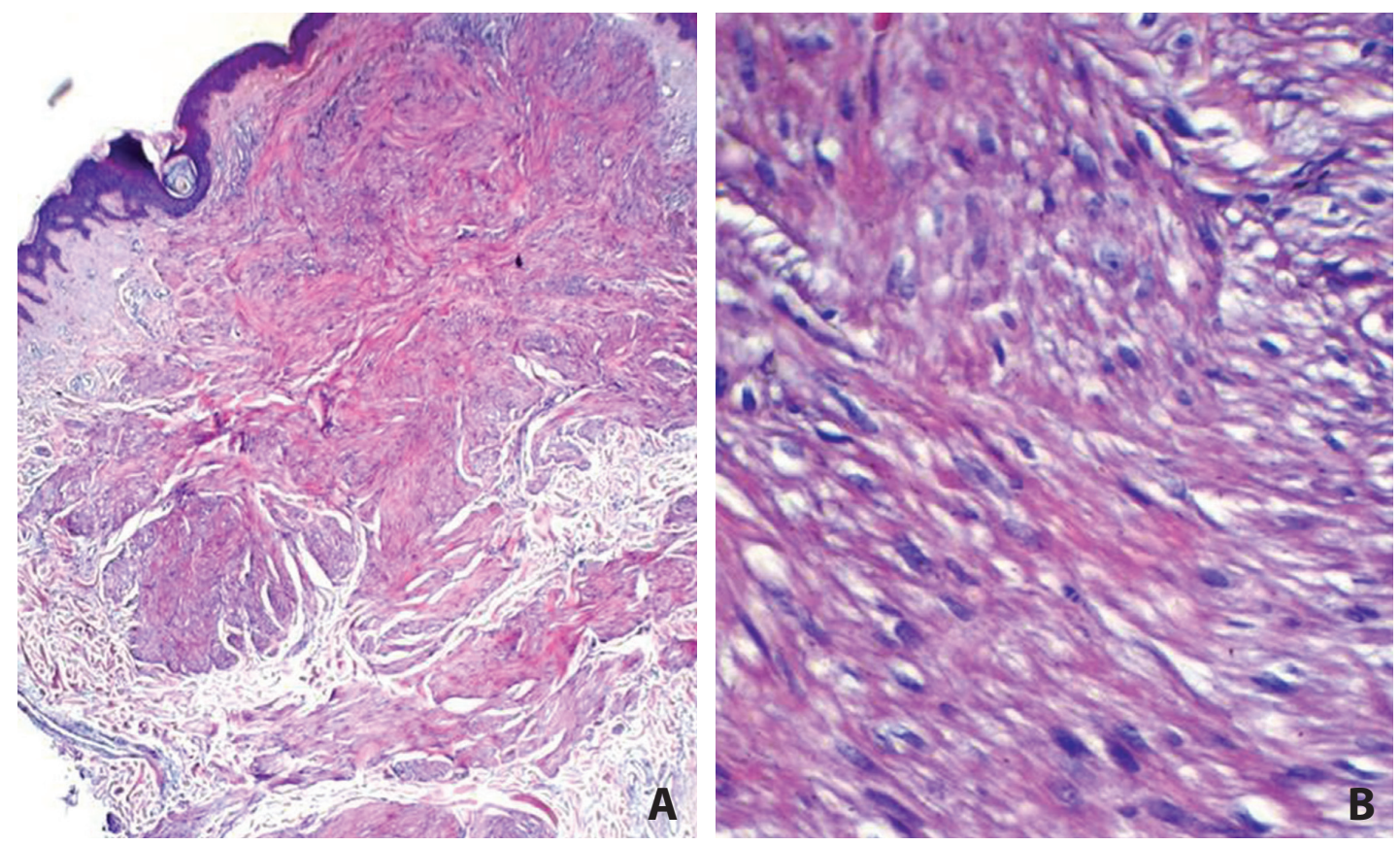

Figure 2. Well-circumscribed nodule composed of spindle cells in the dermis $(\mathbf{A} ; \mathrm{HE} \times 40)$ : without any atypia, mitotic activity and necrosis in the spindle cells (B; HE×400). 
ropeptides, including substance $\mathrm{P}$ and glutamate, thus reducing central pain signals (19).

\section{Conclusion}

In conclusion, although piloleiomyoma is a tumor, it is rare and a benign neoplasm. Other than pain and discomfort seen on the trunk and limbs of the body there are no serious symptoms. The ideal treatment method option is surgery, but the problem with that treatment is that the lesions have tendency to recur. Medicamentous therapy plays a limited role, but calciumchannel blockers and $a$-adrenergic blockers may help in palliating or eliminating associated pain through inhibition of smooth muscle contraction. Due to the rarity of this illness and lack of conclusive treatment it is open for discussion.

\section{Abbreviations \\ MCUL - Multiple Cutaneous and Uterine Leio- myomatosis \\ HLRCC - Hereditary Leiomyomatosis and Renal Cell Carcinoma}

\section{References}

1. Albuquerque MM, Rocha CF, Costa IS, Maia Rda R, Branco FJ, Gonçalves Hde S. Piloleiomyoma with segmental distribution-case report. An Bras Dermatol. 2015;90(3 Suppl 1):178-80.

2. Parreira LM, Sípoli JM, Mercante AM, Orfali RL, Levites J. Case for diagnosis: (unilateral multiple piloleiomyoma). An Bras Dermatol. 2009;84(2):197-9.

3. Kudur $\mathrm{MH}$. A generalized multiple cutaneous piloleiomyomatosis in a young male: rare case report. Indian J Dermatol. 2013;58(3):245.

4. Bernett CN, Mammino JJ. Cutaneous leiomyomas. In: StatPearls. Treasure Island (FL): StatPearls Publishing; 2020.

5. Arishima H, Takeuchi H, Kitai R, Yamauchi T, Kikuta $\mathrm{K}$. Vascular leiomyoma of the scalp with a small de- formity on the skull mimicking a dermoid cyst. Pediatr Dermatol. 2013;30(3):e27-9.

6. Lotfi S, Ghalamkarpour F, Rahimi H, Kani ZA, Yousefi M, Qaisari M. An ulcerated tumor in an infant. Dermatol Online J. 2010;16(4):9.

7. Cairey-Remonnay S, Salard D, Algros MP, Laurent R. Léiomyomes cutanés multiples familiaux. Multiple familial cutaneous leiomyoma. Ann Dermatol Venereol. 2003;130(11):1017-20.

8. Kim DH, Lee JS, Kim JA, Lee JH. Solitary piloleiomyoma in the scalp. Arch Craniofac Surg. 2017;18(1):62-4.

9. Malik K, Patel P, Chen J, Khachemoune A. Leiomyoma cutis: a focused review on presentation, management, and association with malignancy. Am J Clin Dermatol. 2015; 16(1):35-46.

10. Emer JJ, Solomon S, Mercer SE. Reed's syndrome: a case of multiple cutaneous and uterine leiomyomas. $J$ Clin Aesthet Dermatol. 2011;4(12):37-42.

11. Gupta R, Singal A, Pandhi D. Skin-colored nodules in zosteriform pattern. Indian J Dermatol Venereol Leprol. 2006; 72(1):81-2.

12. Pileri A, Ghetti PL, Neri I, Raone B, Ciabatti S, Reggiani $\mathrm{C}$, et al. Atypical piloleiomyoma of the face presenting with central ulceration. Dermatol Reports. 2011;3(3):e50.

13. Malhotra $P$, Walia $H$, Singh $A$, Ramesh V. Leiomyoma cutis: a clinicopathological series of 37 cases. Indian J Dermatol. 2010;55(4):337-41.

14. Idriss $\mathrm{MH}$, Kazlouskaya V, Malhotra S, Andres C, Elston DM. Phosphohistone-H3 and Ki-67 immunostaining in cutaneous pilar leiomyoma and leiomyosarcoma (atypical intradermal smooth muscle neoplasm). J Cutan Pathol. 2013;40(6):557-63.

15. Fernandez-Flores A. Cutaneous leiomyomas and leiomyosarcomas: an immunohistochemical study with p53. Rom J Morphol Embryol. 2010;51(2):295-8.

16. Badeloe S, Frank J. Clinical and molecular genetic aspects of hereditary multiple cutaneous leiomyomatosis. Eur J Dermatol. 2009;19(6):545-51.

17. Scheinfeld $\mathrm{N}$. The role of gabapentin in treating diseases with cutaneous manifestations and pain. Int $\mathrm{J}$ Dermatol. 2003;42(6):491-5.

18. Christenson LJ, Smith K, Arpey CJ. Treatment of multiple cutaneous leiomyomas with $\mathrm{CO}_{2}$ laser ablation. Dermatol Surg. 2000;26(4):319-22.

19. Onder M, Adişen E. A new indication of botulinum toxin: leiomyoma-related pain. J Am Acad Dermatol. 2009;60 (2):325-8.

\section{Piloleiomiom manifestovan u vidu multiplih kutanih nodula - prikaz slučaja}

\section{Sažetak}

Uvod. Piloleiomioma je redak benigni tumor čiji je uzrok mišić erektor dlake a predstavlja 5\% svih leiomioma. Može biti solitaran i multipli, Multiple lezije su još uvek izazov za kliničare pošto su opcije za njihovo lečenje veoma ograničene. Prikaz slučaja. Prikazujemo slučaj dvadesetpetogodišnjeg muškarca, koji je imao bolne papule i nodule na vratu i grudima u trajanju od tri godine. Prilikom fizikalnog pregleda viđene su multiple 
crvenobraon papule i noduli na koži u desnoj mamarnoj regiji i levoj submandibulanroj regiji. Histopatološkim pregledom uzorka panč (punch) biopsije otkriveni su jasno izraženi noduli sastavljeni od vretenastih ćelija. Slučaj je prijavljen kao kutani leiomiom (piloleiomiom). Pacijent je dobio $5 \mathrm{mg}$ amlodipina dnevno i bio je pod kontrolom. Zaključak. Idealna opcija lečenja pilolei- omioma je hirurška ekscizija, ali problem kod tog tretmana je što lezije imaju tendenciju recidiva. Medikamentna terapija ima ograničenu ulogu, ali blokatori kalcijumovih kanala i $a$-adrenergični blokatori mogu pomoći u olakšavanju ili eliminisanju pratećeg bola tako što inhibiraju kontrakciju glatkih mišića.

Ključne reči: Leiomiomi; Kožne neoplazme; Tumori glatkih mišića; Biopsija; Blokatori kalcijumskih kanala; Alfa-adrenergični antagonisti; Retke bolesti

Received 5.07.2020.

Accepted 4.10.2020. 